\title{
Pembentukan Karakter Murid (Studi terhadap Sekolah Dasar Islam Terpadu Al-Fityah Pekanbaru)
}

\author{
YENNI YUNITA \\ Fakultas Agama Islam (FAI) Universitas Islam Riau (UIR)
}

\begin{abstract}
Character education is essentially required to be applied in educational institutions and in the teaching system of education today. Without character education, it means permitting the mix of clarity of understanding of moral values and ambiguous nature which prevent students from making decisions based on a strong moral foundation. This study is a field research which aims to determine the formation of character and factors that influence the formation of character of students at the Al-Fityah Integrated Islamic Primary School Pekanbaru. The type of research is qualitative research. The subject of this study was teachers at the Alfityah Pekanbaru Integrated Islamic Primary School, amounting to 42 people. While the objects in this study were Al-Fityah Islamic Primary School Students totaling 439 people. Data collection techniques in research are observation, interviews, and documentation. Based on the results of this study, it showed that the Formation of students' Characters in the Al-Fityah Integrated Islamic Primary Schools Pekanbaru essentially teaches and implements Islamic manners to students and then refuses them in their daily lives both in the school environment and in the home environment with reference to 10 muwasafat. Character formation is good in the school environment and it directly guided and cared for by the teachers, while at home the character formation of the children is guided by both parents through the Adab Monitoring Book (BMA) and then evaluated by the teacher at school. There are several factors that influence character formation, namely: family or parents, friends, environment, and the influence of television and other electronic media including the internet.
\end{abstract}

Keywords: character formation, students, elementary school, al-fityah Pekanbaru

\begin{abstract}
ABSTRAK: Pendidikan karakter pada hakikatnya wajib diterapkan dalam lembaga pendidikan dan dalam sistem pengajaran di dunia pendidikan saat ini. Tanpa pendidikan karakter, berarti membiarkan campur aduknya kejernihan pemahaman akan nilai-nilai moral dan sifat ambigu yang menghambat para siswa untuk dapat mengambil keputusan berdasarkan landasan moral yang kuat. Penelitian ini merupakan penelitian lapangan (field research) yang bertujuan untuk mengetahui Pembentukan Karakter serta faktor yang mempengaruhi pembentukan Karakter pada murid di Sekolah Dasar Islam Terpadu Al-Fityah Pekanbaru. Jenis penelitian ini adalah penelitian kualitatif. Adapun Subjek penelitian ini adalah Guru di Sekolah Dasar Islam Terpadu Alfityah Pekanbaru yang berjumlah 42 orang. Sedangkan yang menjadi objek dalam penelitian ini adalah Murid Sekolah Dasar Islam Terpadu Al-Fityah Pekanbaru yang berjumlah 439 orang. Teknik pengumpulan data dalam penelitian adalah observasi, wawancara, dan dokumentasi. Berdasarkan hasil penelitian ini, menunjukkan bahwa Pembentukan Karakter Murid di Sekolah Dasar Islam Terpadu Al-Fityah Pekanbaru pada hakikatnya mengajarkan dan menanamkan adab-adab yang islami kepada peserta didik kemudian membiaskaannya dalam kehidupan sehari-hari baik di lingkungan sekolah maupun di lingkungan rumah dengan mengacu kepada 10 muwasafat.
\end{abstract}


Pembentukan karakter yang baik di lingkungan sekolah lansung dibimbing dan diperhatikan oleh guru, sedangkan di rumah pembentukan karakter pada diri anak di bimbing oleh kedua orang tuanya melalui Buku Monitoring Adab (BMA) kemudian dievaluasi oleh guru di sekolah. Ada beberapa faktor yang mempengaruhi pembentukan Karakter yaitu: faktor keluarga atau orang tua, teman, lingkungan, dan pengaruh televisi serta media elektronik lainnya termasuk internet.

Kata kunci: pembentukan karater, murid, sekolah dasar, al-fityah Pekanbaru

\section{PENDAHULUAN}

Mengkaji mengenai masalah pendidikan adalah sesuatu yang senantiasa menarik perhatian. Sebagaimana diketahui bahwa pendidikan merupakan suatu kegiatan yang universal dalam kehidupan manusia. Berbagai konsep dan gagasan yang berbeda-beda menunjukkan bahwa persoalan pendidikan belum selesai. Adanya kemajuan peradaban umat manusia, banyaknya temuan baru dalam berbagai bidang sangat memungkinkan dapat mempengaruhi arah, orientasi, bentuk dan sistem pendidikan Islam yang mana akan meniscayakan para pakar pendidikan memikirkan atau bahkan meninjau konsep-konsep pendidikan yang sudah sekian lama berlaku dan dipercaya.

Pendidikan merupakan upaya manusia secara sadar yang tujuannya bersifat ganda, yaitu mengembangkan kepribadian dan kemampuan manusia. Pendidikan memiliki peran sebagai salah satu cara utama bagaimana masyarakat mempengaruhi perilaku warganya.

Marimba (1980: 131) juga memberikan pengertian bahwa: pendidikan Islam adalah "bimbingan jasmani dan rohani berdasarkan hukumhukum agama Islam menuju kepada terbentuknya kepribadian utama menurut ukuran-ukuran Islam. Dengan memperhatikan kedua definisi diatas maka berarti pendidikan Islam adalah suatu proses yang mengarah kepada pembentukan karakter atau kepribadian seseorang berdasarkan tuntunan syari'at Islam yaitu Al-Qur'andan Hadist.

Allah SWT memerintahkan kepada manusia agar mencontoh kepribadian atau karakternya Rasulullah SAW dengan menjadikan beliau sebagai suri teladan yang pantas diteladani dalam kehidupan. Begitu juga dengan siswa di sekolah tentu mereka mencontoh kepribadian atau karakter gurunya dengan menjadikannya sebagai suri teladan dalam mengikuti proses belajar di sekolah. Untuk itu, hendaknya guru juga memiliki figur yang bisa dijadikan teladan bagi dirinya yang akan diikuti oleh anak didiknya. Allah SWT berfirman:

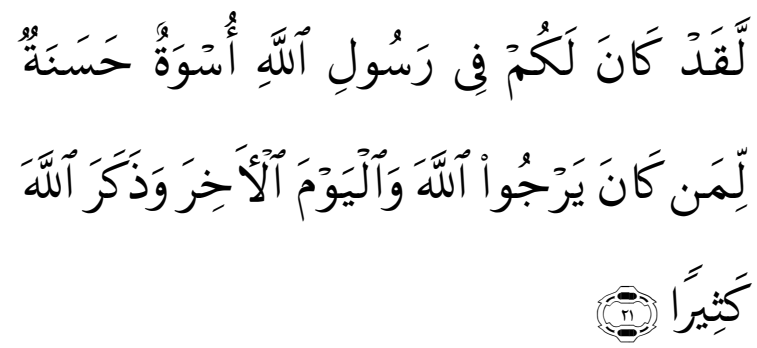

Artinya: "Sesungguhnya Telah ada pada (diri) Rasulullah itu suri teladan yang baik bagimu (yaitu) bagi orang yang mengharap (rahmat) Allah dan (kedatangan) hari kiamat dan dia banyak menyebut Allah" (Q.S. Al-Ahzab: 21)

Disamping itu, pembentukan karakter dari sudut pandang Islam AlGhazali mengatakan bahwa sumber pembentukan karakter yang baik itu dapat dibangun melalui internalisasi 
nama-nama Allah (asma' al-Husna) dalam perilaku seseorang. Artinya, untuk membangun karakter yang baik, sejauh kesanggupannya, manusia meniru-niru perangai dan sifat-sifat ketuhanan, seperti pengasih, penyayang, pengampun (pemaaf), dan sifat-sifat yang disukai Tuhan, sabar, jujur, takwa, zuhud, ikhlas beragama, dan sebagainya. Sumber kebaikan manusia terletak pada kebersihan rohaninya dan taqarub kepada Tuhan. Karena itu, Al-Ghazali tidak hanya mengupas kebersihan badan lahir tetapi juga kebersihan ruhani.

Dewasa ini, pendidikan di Indonesia sangat memprihatinkan, dimana nilai-nilai yang menjadi budaya bangsa Timur yang cendrung untuk selalu mengedepankan nilai moralitas, etika masyarakat yang berbudi luhur serta menjunjung tinggi nilai-nilai religius sesuai jati diri dan kepribadian bangsa. Sekarang ini, banyak di antara generasi muda terkena penyakit "dekadensi moral" seperti kekerasan, tawuran antar pelajar, pemerkosaan, kasus hamil diluar nikah, penggunaan obat-obat terlarang, minuman keras, berjudi, portitusi dan lain sebagainya sehingga kelihatan seperti sudah menjadi sesuatu yang wajar-wajar saja. Sehingga hal ini juga yang menjadi salah satu penyebab bagi bangsa Indonesia kehilangan budaya aslinya.

Sekolah yang sadar akan tanggung jawabnya terhadap perannya harus berfungsi sebagai lembaga pengajaran, tetapi apakah proses pembelajaran hanya memperhatikan ranah kognitif saja? Apakah ada tempat dan waktu untuk menanamkan nilainilai untuk pembentukan karakter? Jawabannya singkatnya, jelas ada karena pelajar harus tumbuh mencapai yang lebih dari sekedar keunggulan akademis semata-mata. Penanaman nilai dan pendidikan karakter tentu menjadi tujuan utama pengajaran untuk menjadikan manusia dewasa dan mandiri.

Pendidikan karakter menjadi sangat penting untuk diterapkan dalam lembaga pendidikan dan dalam sistem pengajaran di dunia pendidikan sekarang ini. Tanpa pendidikan karakter, berarti membiarkan campur aduknya kejernihan pemahaman akan nilai-nilai moral dan sifat ambigu yang menyertai, yang pada gilirannya menghambat para siswa untuk dapat mengambil keputusan yang memiliki landasan moral yang kuat. Pendidikan karakter akan memperluas wawasan para pelajar tentang nilai-nilai moral dan etnis yang membuat mereka semakin mampu mengambil keputusan yang secara moral dapat dipertanggungjawabkan.

Pendidikan karakter yang dimaksudkan disini lebih berkaitan dengan bagaimana menanamkan nilainilai tertentu dalam diri anak didik, seperti nilai-nilai yang berguna bagi pengembangan pribadinya sebagai makhluk individual sekaligus Sosial dalam lingkungan sekolah (Marimba, 1980: 192).

Salah satu sekolah yang tengah menerapkan pendidikan karakter adalah Sekolah Dasar Islam Terpadu AlFityah Pekanbaru, di mana Sekolah Dasar Islam Terpadu (SDIT) merupakan sebuah lembaga pendidikan yang bercirikan Islam dengan mengimplementasikan konsep pendidikan Islam berlandaskan AlQur'an dan Sunnah yang setaraf dengan sekolah dasar umum biasa yang memadukan kurikulum standar sekolah negeri dengan pendidikan agama Islam. Sistem pembelajaran yang diterapkan di SDIT bersifat aplikatif diantaranya tematik pada kelas I sampai kelas III, dimana pembelajaran diberikan dengan menentukan tema yang diperkuat dengan dalil al-Qur'an dan dihubungkan dengan kehidupan 
keseharian siswa dan Active Learning pada kelas IV sampai VI, di mana siswa dilibatkan dengan maksimal pada setiap kegiatan pembelajaran dan proses pendidikandan tanpa terkecuali Multile Intelegences juga di terapkan di sekolah ini.

Dari keterangan di atas penulis tertarik membahas masalah ini untuk mendalami lebih lanjut letak keunggulan di sekolah ini dalam rangka menjawab permasalahan yang terjadi dalam sistem pendidikan sekarang yang belum sesuai dengan apa yang diharapkan oleh para orang tua dan masyarakat pada umumnya. Dengan demikian penulis akan mengadakan penelitian ini dengan judul “ Pembentukan Karakter Murid (Studi terhadap Sekolah Dasar Islam Terpadu Al-Fityah Pekanbaru)".

Adapun rumusan permasalahan dalam penelitian ini adalah sebagai berikut: (a) Bagaimana Pembentukan Karakter Murid di Sekolah Dasar Islam Terpadu Al-Fityah Pekanbaru ?; dan (b) Apa saja faktor yang mempengaruhi pembentukan Karakter Murid di Sekolah Dasar Islam Terpadu Al-Fityah Pekanbaru?

Berdasarkan perumusan masalah di atas, maka penelitian ini bertujuan untuk; (a) Mengetahui Pembentukan Karakter Murid di Sekolah Dasar Islam Terpadu Al-Fityah Pekanbaru; dan (b) Mengetahui faktor yang mempengaruhi pembentukan Karakter Murid di Sekolah Dasar Islam Terpadu Al-Fityah Pekanbaru.

Penelitian Terdahulu yang juga meneliti tentang pendidikan karakter, yakni: (1) Pendidikan Karakter; Strategi Mendidik anak di zaman Global karangan Doni Koesoema A tahun 2007. Dalam buku ini menggambarkan tentang urgensi dan metodologi pendidikan karakter serta nilai-nilai dan prinsipprinsip dasar dalam pendidikan karkter; (2) Strategi Kepala Sekolah dalam menerapkan program pendidikan berbasis budi pekerti di SMA Negeri 7 Pekanbaru, ditulis oleh Muhammad Syafe'i tahun 2007. Tesis ini menggambarkan tentang bagaiman strategi kepala sekolah SMA Negeri 7 Pekanbaru terhadap program pendidikan berbasis budi pekerti dan upaya-upaya yang dilakukan dalam meningkatkan prilaku moral siswa di sekolah kemudian strategi Kepala sekolah dalam mengintegrasikan nilainilai budi pekerti ke dalam bidang studi PPKN; bahasa-sastra Indonesia dan agama di SMA Negeri 7 Pekanbaru; dan (3) Metode Pendidikan Keluarga dalam Islam (Studi atas Pembentukan kepribadian Anak), ditulis oleh Mualif seorang mahasiswa STAIN Surakrta tahun 2007. Dari hasil penelitiaanya bahwa skripsi ini mengungkapakan tentang upaya orang tua dalam mendidik anak serta membangun pribadi anak untuk menumbuhkan jiwa anak, proses membentuk kepribadian atau tingkah laku anak hendaknya dimulai dari masa anak-anak. Dengan demikian orang tua harus memperhatikan perkembangan dan pertumbuhan jiwa anak karena orang tua sangat berpengaruh dalam kehidupan anak.

Konsep Operasional dalam penelitian ini adalah: (1) Guru membiasakan murid memiliki tubuh yang sehat, terlihat dari keaktifannya dalam berolahraga dan melaksanakan kegiaatan ekstrakurikuler dengan baik; (2) Guru membiasakan murid memiliki perilaku yang kokoh baik lahiriah maupun batiniah, dengan kepatuhan dalam memegang teguh prilaku Rasulullah SAW dan memiliki akhlak Islami yang tercermin dari akhlak yang disifati oleh Allah dipraktekkan dalam kehidupan sehari-hari; (3) Guru membiasakan murid memiliki wawawasan luas diantaranya wawasan keislaman yang meliputi ilmu pengetahuan tentang akidah, ibadah, 
berbagai masalah alam gaib, masalah AlQur'an, bahasa Arab, sejarah Islam serta wawasan umum; (4) Guru membiasakan murid memiliki kemampuan berusaha yang terlihat dari potensi dan bakat yang dimilikinya untuk merencanakan masa depan dengan pekerjaan atau usaha tertentu; (5) Guru membiasakan murid mau menjadi muslim yang berakidah benar terbebas dari paham kemusyrikan; (6) Guru membiasakan murid mau menjadi muslim yang beribadah secara benar sesuai dengan tuntunan syariat Islam berdasarkan AlQur'an dan Sunnah; (7) Guru membiasakan murid mampu memerangi hawa nafsu yang menyuruh pada keburukan; (8) Guru membiasakan murid memiliki disiplin waktu terlihat dari kehadirannya, jam istirahat, waktu belajar dan pelaksaan ibadahnya; (9) Guru membiasakan murid menjalankan segala urusan secara sistematis, teratur, dan memiliki acuan yang jelas dalam melaksanakan pekerjaannya sebagai seorang murid; dan (10) Guru mengajarkan kepada murid agar bermanfaat bagi orang lain yang bertitik tolak dari kecendrungan untuk berbuat baik kepada semua orang.

\section{LANDASAN TEORI \\ Konsep Karakter}

Kata karakter menurut Pusat Bahasa Depdiknas artinya adalah "bawaan, hati, jiwa, kepribadian, budi pekerti, perilaku, personalitas, sifat, tabiat, temperamen, watak". Berkarakter adalah berkepribadian, berperilaku, bersifat, bertabiat, dan berwatak".

Karakter berasal dari bahasa Yunani yang berarti "to mark" atau menandai dan memfokuskan bagaimana mengaplikasikan nilai kebaikan dalam bentuk tindakan atau tingkah laku, sehingga orang yang tidak jujur, kejam, rakus dan perilaku jelek lainnya dikatakan orang berkarakter jelek. Sebaliknya, orang yang perilakunya sesuai dengan kaidah moral disebut dengan berkarakter mulia.

Karakter merupakan nilai-nilai perilaku manusia yang berhubungan dengan Tuhan Yang Maha Esa, diri sendiri, sesama manusia, lingkungan, dan kebangsaan yang terwujud dalam pikiran, sikap, perasaan, perkataan, dan perbuatan berdasarkan norma-norma agama, hukum, tata krama, budaya, dan adat istiadat.

Individu yang berkarakter baik atau unggul adalah seseorang yang berusaha melakukan hal-hal yang terbaik terhadap Tuhan YME, dirinya, sesama, lingkungan, bangsa dan negara serta dunia internasional pada umumnya dengan mengoptimalkan potensi (pengetahuan) dirinya dan disertai dengan kesadaran, emosi dan motivasinya (perasaannya).

\section{Pendidikan Karakter}

Pendidikan karakter adalah suatu sistem penanaman nilai-nilai karakter kepada warga sekolah yang meliputi komponen pengetahuan, kesadaran atau kemauan, dan tindakan untuk melaksanakan nilai-nilai tersebut, baik terhadap Tuhan Yang Maha Esa (YME), diri sendiri, sesama, lingkungan, maupun kebangsaan sehingga menjadi manusia insan kamil. Dalam pendidikan karakter di sekolah, semua komponen (stakeholders) harus dilibatkan, termasuk komponen-komponen pendidikan itu sendiri, yaitu isi kurikulum, proses pembelajaran dan penilaian, kualitas hubungan, penanganan atau pengelolaan mata pelajaran, pengelolaan sekolah, pelaksanaan aktivitas atau kegiatan kokurikuler, pemberdayaan sarana prasarana, pembiayaan, dan ethos kerja seluruh warga dan lingkungan sekolah. 
Lebih lanjut dari keterangan di atas dijelaskan bahwa, pendidikan karakter adalah segala sesuatu yang dilakukan guru, yang mampu mempengaruhi karakter peserta didik. Guru membantu membentuk watak peserta didik. Hal ini mencakup keteladanan bagaimana perilaku guru, cara guru berbicara atau menyampaikan materi, bagaimana guru bertoleransi, dan berbagai hal terkait lainnya.

Pendidikan karakter dapat diintegrasikan dalam pembelajaran pada setiap mata pelajaran. Materi pembelajaran yang berkaitan dengan norma atau nilai-nilai pada setiap mata pelajaran perlu dikembangkan, dieksplisitkan, dikaitkan dengan konteks kehidupan sehari-hari. Dengan demikian, pembelajaran nilai-nilai karakter tidak hanya pada tataran kognitif, tetapi juga menyentuh pada internalisasi dan pengamalan nyata dalam kehidupan peserta didik seharihari di masyarakat.

\section{Pembentukan Karakter}

Allah SWT memerintahkan kepada manusia agar mencontoh kepribadian atau karakternya Rasulullah SAW dengan menjadikan beliau sebagai suri tauladan yang pantas diteladani dalam kehidupan. Begitu juga dengan siswa di sekolah tentu mereka mencontoh kepribadian atau karakter gurunya dengan menjadikannya sebagai suri tauladan dalam mengikuti proses belajar di sekolah. Untuk itu, hendaknya guru juga memiliki figur yang bisa dijadikan tauladan bagi dirinya yang akan diikuti oleh anak didiknya. Allah SWT menggambarkan kepribadian Rasululllah SAW sebagai figur yang memiliki karakter yang baik seperti terdapat dalam Al-Qur'an surat AlAhzab ayat 21, yang berbunyi:

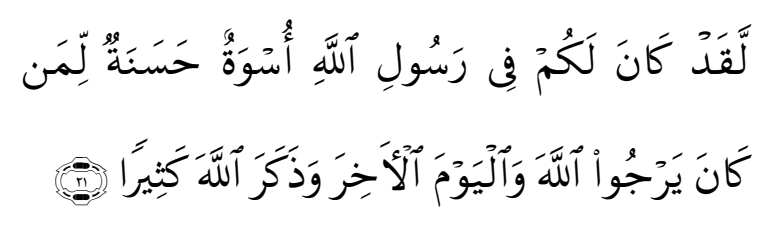

Artinya: "Sesungguhnya Telah ada pada (diri) Rasulullah itu suri teladan yang baik bagimu (yaitu) bagi orang yang mengharap (rahmat) Allah dan (kedatangan) hari kiamat dan dia banyak menyebut Allah" (Q.S. Al-Ahzab: 21)

Ayat di atas juga diperkuat dengan hadis Rasulullah SAW, yang berbunyi:

"Dari Abu Hurairah bersabda Rasulullah SAW: Sesungguhnya aku diutus ke dunia adalah untuk menyempurnakan akhlak manusia" (Hanbal, 1994: 210).

Berdasarfkan ungkapan hadis tersebut dapat diketahui bahwa Rasulullah SAW sebagai nabi dan rasul terakhir yang membawa berkah bagi sekalian alam, dimana beliau adalah sosok seorang figur yang pantas dijadikan teladan bagi seluruh umat manusia yang ada di permukaan bumi Allah SWT. Sebagaimana firman Allah SWT dalam surat al-Anbiya' ayat 107 yang berbunyi:

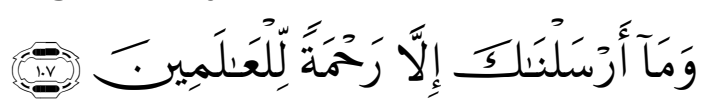

Artinya: "Dan tiadalah kami mengutus kamu, melainkan untuk (menjadi) rahmat bagi semesta alam".(QS.Al-Anbiya'a: 107)

Berdasarkan dalil-dalil yang disebutkan di atas, dapat diketahui bahwa pembentukan karakter anak atau akhlak pada prinsipnya dapat terwujudkan jika ada figur yang pantas dijadikan teladan yang baik (uswatun hasanah) kalau di sekolah berarti harus ada guru yang memiliki kepribadian atau karakter yang baik agar menjadi teladan bagi anak didiknya di lingkungan sekolah begitu juga dirumah 
orang tualah yang menjadi teladan yang baik bagi anaknya.

Ada 10 sifat karakter atau nilainilai yang perlu ditanamkan pada individu seseorang antara lain: Pertama, Salīmul 'Aqìdah (Aqidah yang bersih). Aqidah yang bersih (salimmul 'aqidah) merupakan sesuatu yang harus ada pada setiap muslim. Dengan aqidah yang bersih, seorang muslim akan memiliki ikatan yang kuat kepada Allah Swt dan dengan ikatan yang kuat itu dia tidak akan menyimpang dari jalan dan ketentuan-ketentuan-Nya. Allah SWT berfirman:

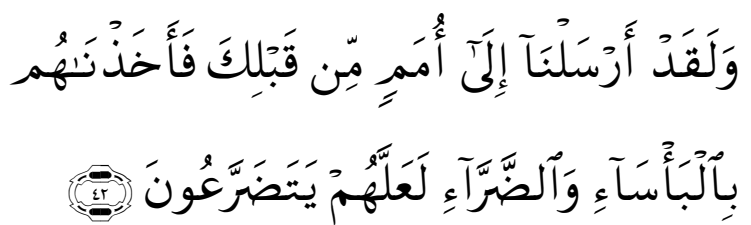

Artinya: "Katakanlah: Sesungguhnya sembahyangku, ibadatku, hidupku dan matiku hanyalah untuk Allah, Tuhan semesta alam". (QS.Al-An'am: 162)

Karena memiliki aqidah yang salim merupakan sesuatu yang amat penting, maka dalam da'wahnya kepada para sahabat di Makkah, Rasulullah Saw mengutamakan pembinaan aqidah, iman atau tauhid.

\section{Kedua, Shahīhul 'Ibādah}

(Ibadah yang benar). Ibadah yang benar (shahīhul 'ibādah) merupakan salah satu perintah Rasul Saw yang penting, dalam satu haditsnya; beliau menyatakan: "shalatlah kamu sebagaimana kamu melihat aku shalat". Dari ungkapan ini maka dapat disimpulkan bahwa dalam melaksanakan setiap peribadatan haruslah merujuk kepada sunnah Rasul Saw yang berarti tidak boleh ada unsur penambahan atau pengurangan. Ketiga, Matīnul Khuluq (Akhlak yang kokoh). Akhlak yang kokoh (matinul khuluq) atau akhlak yang mulia merupakan sikap dan prilaku yang harus dimiliki oleh setiap muslim, baik dalam hubungannya kepada Allah maupun dengan makhluk-makhluk-Nya. Dengan akhlak yang mulia, manusia akan bahagia dalam hidupnya, baik di dunia apalagi di akhirat.

Keempat, Qowiyyul Jismi

(kuat jasmani). Kekuatan jasmani (qowiyyul jismi) merupakan salah satu sisi pribadi muslim yang harus ada. Kekuatan jasmani berarti seorang muslim memiliki daya tahan tubuh sehingga dapat melaksanakan ajaran Islam secara optimal dengan fisiknya yang kuat. Shalat, puasa, zakat dan haji merupakan amalan di dalam Islam yang harus dilaksanakan dengan fisik yang sehat atau kuat, apalagi perang di jalan Allah dan bentuk-bentuk perjuangan lainnya.

Kelima, Mutsaqqoful Fikri (Intelek dalam berpikir). Intelek dalam berpikir (mutsaqqoful fikri) merupakan salah satu sisi pribadi muslim yang penting. Karena itu salah satu sifat Rasul adalah fatonah (cerdas) dan Al-Qur'an banyak mengungkap ayat-ayat yang merangsang manusia untuk berpikir, misalnya firman Allah:

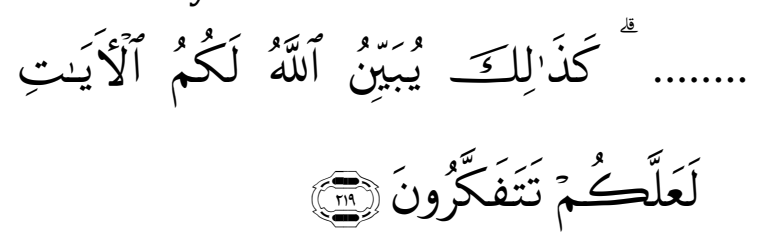

Artinya: "...... Demikianlah Allah menerangkan ayat-ayat-Nya kepadamu supaya kamu berfikir. (QS.AL-Baqarah: 219).

Keenam,

Mujāhadatul Linafsihi (Berjuang Melawan hawa nafsu). Berjuang melawan hawa nafsu (mujāhadatul linafsihi) merupakan salah satu kepribadian yang harus ada pada diri seorang muslim, karena setiap 
manusia memiliki kecenderungan pada yang baik dan yang buruk. Melaksanakan kecenderungan pada yang baik dan menghindari yang buruk amat menuntut adanya kesungguhan dan kesungguhan itu akan ada manakala seseorang berjuang dalam melawan hawa nafsu. Oleh karena itu hawa nafsu yang ada pada setiap diri manusia harus diupayakan tunduk pada ajaran Islam, Rasulullah Saw bersabda yang artinya: Tidak beriman seseorang dari kamu sehingga ia menjadikan hawa nafsunya mengikuti apa yang aku bawa (ajaran islam) (HR. Hakim).

$$
\text { Ketujuh, Harishun 'Ala }
$$

Waqtihi (Pandai menjaga waktu). Pandai menjaga waktu (harishun 'ala waqtihi) merupakan faktor penting bagi manusia. Hal ini karena waktu itu sendiri mendapat perhatian yang begitu besar dari Allah dan Rasul-Nya. Allah Swt memberikan waktu kepada manusia dalam jumlah yang sama setiap, yakni 24 jam sehari semalam. Dari waktu yang 24 jam itu, ada manusia yang beruntung dan tak sedikit manusia yang rugi. Waktu merupakan sesuatu yang cepat berlalu dan tidak akan pernah kembali lagi. Oleh karena itu setiap muslim amat dituntut untuk mengatur waktunya dengan baik, sehingga waktu dapat berlalu dengan penggunaan yang efektif, tak ada yang sia-sia.

\section{Kedelapan, Munazhzhamun fi \\ Syu'unihi (Teratur dalam urusan).} Teratur dalam suatu urusan (munzhzhamun fi syu'unihi) termasuk kepribadian seorang muslim yang ditekankan oleh Al-Qur'an maupun sunnah. Oleh karena itu dalam hukum Islam, baik yang terkait dengan masalah ubudiyah maupun muamalah harus diselesaikan dan dilaksanakan dengan baik. Ketika suatu urusan ditangani secara bersama-sama, maka diharuskan bekerjasama dengan baik sehingga Allah menjadi cinta kepadanya. Dengan kata lain, suatu urusan dikerjakan secara profesional, sehingga apapun yang dikerjakannya, profesionalisme selalu mendapat perhatian darinya. Kesembilan, Qodirun 'Alal Kasbi (Mampu berusaha sendiri atau mandiri). Memiliki kemampuan usaha sendiri atau yang juga disebut dengan mandiri (qodirun 'alal kasbi) merupakan ciri lain yang harus ada pada seorang muslim. Ini merupakan sesuatu yang amat diperlukan. Dalam kaitan menciptakan kemandirian inilah seorang muslim amat dituntut memiliki keahlian apa saja yang baik, agar dengan keahliannya itu menjadi sebab baginya mendapat rizki dari Allah Swt, karena rizki yang telah Allah sediakan harus diambil dan mengambilnya memerlukan skill atau ketrampilan.

Kesepuluh, Nafi'un Lighoirihi (Bermanfa'at bagi orang lain). Bermanfaat bagi orang lain (nafi'un lighoirihi) merupakan sebuah tuntutan kepada setiap muslim. Manfaat yang dimaksud tentu saja manfaat yang baik sehingga dimanapun dia berada, orang disekitarnya merasakan keberadaannya karena bermanfaat besar. Dalam kaitan inilah, Rasulullah saw bersabda yang artinya: sebaik-baik manusia adalah yang paling bermanfaat bagi orang lain (HR. Qudhy dari Jabir).

\section{Faktor-Faktor yang Mempengaruhi Pembentukan Karakter Anak}

Dalam perspektif Islam, manusia dipahami sebagai makhluk yang memiliki potensi fitrah dimana terdapat daya-daya yang dapat memunculkan sebuah sikap dan perilaku yang tidak lepas dari stimulus dari luar. Artinya, Islam memandang karakter manusia tidak murni karena faktor potensi, tetapi juga faktor lingkungan yang mempengaruhinya.

Lingkungan sosial manusia adalah faktor penting dalam pembentukan ciri khas kejiwaan dan norma manusia, 
bahasa dan adab serta kearifan lokal. Agama dan mazhablah pada umumnya yang memaksakan lingkungan sosial terhadap manusia.

Lingkungan jika dihadapkan dengan genetik adalah faktor luar yang berpengaruh dalam pembentukan dan perubahan kepribadian seseorang baik itu faktor-faktor lingkungan pra kelahiran atau pasca kelahiran yang mencakup lingkungan alam, lingkungan ekonomi dan lingkungan sosial. Lingkungan sosial juga mencakup lingkungan keluarga, sekolah, mazhab dan sebaginya.

Ayah dan ibu adalah teladan pertama bagi pembentukan pribadi anak. Keyakinan-keyakinan, pemikiran dan perilaku ayah dan ibu dengan sendirinya memiliki pengaruh yang sangat dalam terhadap pemikiran dan perilaku anak. Karena kepribadian manusia muncul berupa lukisan-lukisan pada berbagai ragam situasi dan kondisi dalam lingkungan keluarga.

Keluarga berperan sebagai faktor pelaksana dalam mewujudkan nilainilai, keyakinan-keyakinan dan persepsi budaya sebuah masyarakat. Ayah dan ibulah yang harus melaksanakan tugasnya di hadapan anaknya. Khususnya ibu yang harus memfokuskan dirinya dalam menjaga akhlak, jasmani dan kejiwaannya pada masa pra kehamilan sampai masa kehamilan dengan harapan Allah memberikan kepadanya anak yang sehat dan saleh.

\section{METODE PENELITIAN}

Penelitian ini merupakan penelitian lapangan (field research) yang bersifat kualitatif, yaitu sebuah penelitian yang cendrung bersifat deskriptif, naturalistik dan berhubungan dengan sifat data yang murni kualitatif (Irawan, 1994: 70).
Subjek penelitian ini adalah guru atau dikenal dengan sebutan ustaz atau ustazah di Sekolah Dasar Islam Terpadu Alfityah Pekanbaru yang berjumlah 42 orang. Sedangkan yang menjadi objek dalam penelitian ini adalah karakter murid Sekolah Dasar Islam Terpadu AlFityah Pekanbaru yang berjumlah 439 orang.

data dalam teknik pengumpulan pembentukan karakter murid (studi di Sekolah Dasar Islam Terpadu Al-Fityah Pekanbaru) dilakukan dengan menggunakan alat pengumpulan data sebagai berikut: (1) Observasi, yaitu suatu metode pengumpulan data melalui proses pengamatan langsung di lapangan untuk mendapatkan gambaran langsung tentang subjek yang diteliti yaitu di Sekolah Dasar Islam Terpadu Alfityah Pekanbaru; dan (2) Wawancara. Menurut Arikounto (1997: 145), wawancara adalah sebuah dialog yang dilakukan pewawancara (interviewer) untuk memperoleh informasi dari terwawancara (interviwee).

Dalam penelitian ini, di mana teknik pengumpulan data dengan wawancara penulis tujukan kepada guru di Sekolah Dasar Islam Terpadu Al Fityah Pekanbaru yang bertujuan untuk mengetahui bagaimana proses pembentukan karakter yang dilakukan oleh guru terhadap murid di Sekolah Dasar Islam Terpadu Al Fityah Pekanbaru dan apa saja faktor-faktor yang mempengaruhi karakter murid tersebut.

Adapun teknik analisis data, dimana setelah data yang diperlukan terkumpul, peneliti melakukan analisa data dengan menggunakan langkahlangkah seperti yang dikemukakan Milles dan Huberman yang secara umum terdidri dari empat alur kegiatan, yaitu: (1) pengumpulan data, (2) reduksi data, (3) penyajian data, dan (4) menarik 
kesimpulan/verifikasi

Huberman, 1987: 21).

\section{HASIL}

\section{Gambaran Umum SD Al-Fityah Pekanbaru}

Yayasan $\mathrm{Al}$ Fityah didirikan tanggal 21 Juni 1993 Masehi atau tanggal 01 Muharram $1414 \mathrm{H}$. Pada awal pendidirian Yayasan, yang menjadi pengurus harian langsung dipegang oleh orang-orang terlibat sebagai dewan pendiri. Dan pada tahun-tahun berikutnya Yayasan Al Fityah sudah bisa mendirikan Sekolah Taman KanakKanak yang diberi nama TK Permata, berlokasi di Lantai II Toko Buku Sakinah Jln. Nangka Pekanbaru.

Mengingat urgennya Yayasan ini, maka pada tanggal 07 Mei 2000 ini, dikumpulkan beberapa orang yang bisa menjalankan Yayasan Al Fityah dengan lebih baik. Pada saat itu 10 orang muda berpengalaman yang akhirnya dinobatkan sebagai formatur sekaligus tim kecil dalam perumusan langkah awal perjalanan Al Fityah.

$$
\text { Tanggal } 7 \text { Oktober } 2000
$$

dilakukan penyisipan pengurus sehingga berjumlah 25 orang, dan waktu itu juga dibentuk tim pendirian SDIT yang terdiri dari 12 orang dengan Bapak Al Fatmi sebagai ketua Tim. Dari hasil musyawarah rutin ditargetkan Juli tahun 2001 SDIT Al Fityah sudah berdiri. Dengan izin Allah, kerja keras dan pengorbanan para pengurus akhirnya Juni 2001 bangunan SDIT berdiri.

Visi dari SDIT Al Fityah adalah: "Menjadikan Lembaga Pendidikan Dasar Terbaik Riau". Sedangkan misi SDIT Al Fityah yang terbaru adalah: (a) Menghasilkan generasi berprestasi dan berakhlaq islami serta dekat dengan AlQur'an; (b) Membangun kemampuan diri dalam mengenal dan berinteraksi dengan lingkungan; (c) Mempersiapkan diri siswa agar mampu beradaptasi dengan kemajuan teknologi, serta membekalinya dengan penguasaan ilmu pengetahuan serta implementasinya secara optimal; dan (d) Menghasilkan generasi yang mampu berkomunikasi dengan bahasa Arab dan Inggris dengan baik dan benar.

Sampai saat ini SDIT Al Fityah sudah memiliki gedung sebanyak 7 kelas dan TK 5 kelas dilengkapi dengan Musholla dan ruang komputer. Halaman sudah di paving block, dan rencana tahun ini akan dibangun gedung permanen sebanyak 3 lantai dengan jumlah sembilan kelas.

Jumlah guru di SDIT Al Fityah yang tingkat pendidikannya S2 adalah 1 orang, S1 adalah 37 orang, D1 adalah 1 orang dan SLTA adalah 3 orang. Total keseluruhan guru dan karyawan adalah 42 orang.

Pada tahun 2011 diketahui bahwa jumlah siswa kelas 1 adalah 73 orang, kelas II adalah 85 orang, kelas III adalah 83 orang, kelas IV adalah 88 orang, Kelas V adalah 55 orang, dan kelas 6 adalah 55 orang. Total keseluruhan siswa adalah 439 orang.

Minat masyarakat terhadap program yang ditawarkan oleh Sekolah Islam Terpadu khususnya SDIT Al Fityah dari waktu ke waktu semakin besar ini terbuktinya dengan bertambahnya jumlah siswa SDIT dari tahun ketahun.

Ada 3 (tiga) kurikulum pokok yang digunakan di SDIT Al Fityah Pekanbaru, yakni: (1) Kurikulum Depdiknas; (2) Kurikulum Matrikulasi; dan (3) Kurikulum Khas SDIT Al Fityah. Kurikulum khas ini mencakup: (a) Tahsin dan Tahfiz; (b) Bahasa Arab; (c) Pramuka SIT; dan (d) Pembinaan keislaman (mentoring Islam).

Proses pembelajaran dan pendidikan secara formal berlansung selama lima hari (Senin s.d Jum'at) hari Sabtu digunakan untuk kegiatan ekstra kurikuler dalam rangka memberikan 
ruang eksplorasi dan ekspresi siswa menurut kecendrungan dan bakat yang dimilikinya.

\section{Pembentukan Karakter Murid di Sekolah Dasar Islam Terpadu Al- Fityah Pekanbaru}

Adapun Pembentukan Karakter Murid di Sekolah Dasar Islam Terpadu Al-Fityah Pekanbaru dapat dilihat dari petikan beberapa hasil wawancara penulis di antaranya dengan Ustazah(U1) sebagai guru kelas III AlBahi pada tanggal 24 Mei 2011 yang mengemukakan bahwa:

"Di Sekolah Dasar Islam Terpadu Al-Fityah Pekanbaru yang berlandaskan sekolah berkarakter, dimana pembentukan karakter pada diri murid terlihat dari Buku Monitoring Adab (BMA) murid yang sangat berpengaruh terhadap hasil ujian akhir semester murid sebanyak 20\%. Dalam pembelajaran saya menerapkan sistem pembelajaran active learning dengan pembelajaran tematik. Waktu untuk mata pelajaran Qira'ati lebih banyak dan lebih sering diberikan kepada murid dan pada mata pelajaran ini juga mengandung unsur pembentukan karakter pada diri murid. Di samping itu, pembentukan karakter pada murid juga terlihat dari penerapan adab-adab islami yang sudah dibekali sejak kelas I kemudian dipraktekkan dilingkungan sekolah. Walaupun di sekolah ini terkenal full day dari pagi sampai sore tetapi sekolah mengatur waktu sedemikian rupa termasuk dalam pembiasaan karakter yang baik, seperti pada pagi hari sebelum masuk kelas seluruh murid melaksanakan sholat dhuha kemudian tilawah Al-Qur'an baru belajar dan pada sa'at proses pembelajaran bahkan jam istirahat pun seorang guru tetap berusaha mengajarkan kebiasaan karakter yang baik."
Hal yang sama juga disampaikan oleh Ustazah(U2) sebagai wali kelas I Ibnu Katasir pada tanggal 27 Mei 2011 yang mengemukakan bahwa:

"Pembentukan karakter di sekolah ini lebih menitikberatkan pada penanaman akhlak yang baik, yang terlihat dari pembiasaan adab-adab islami yang diberikan kepada murid pada awal permulaan masuk ke sekolah ini dalam kehidupan sehari-hari selama 3 bulan kemudian disusul dengan kontrak belajar antara guru dengan murid. Adapun pembentukan karakter pada diri murid juga perlu dukungan dari pihak keluarga diantaranya dengan adanya buku monitoring adab yang mesti diisi oleh orang tua murid setiap hari."

Untuk menguatkan pernyataan di atas penulis melalukan wawancara dengan Ustazah(U3) sebagai wali kelas III Al-Bahi pada tanggal 30 Mei 2011 yang mengemukakan bahwa:

"Menurut saya pembentukan karakter murid artinya mengembangkan karakter dasar yang sudah ada melekat pada diri anak sebagaimana dikatakan dalam hadis Nabi yang mengungkapkan tentang setiap anak yang lahir dalam keadaan fitrah. Pembentukan karakter yang diajarkan di sekolah dengan cara menanamkan nilai-nilai Islam dalam bentuk mengenalkan adab-adab islami kepada murid. Adapun prinsip yang dikembangakan dalam pembentukan karakter murid di sekolah ini berdasarkan 10 muwassafat. Mengenai sistem pembelajarannya disini menerapkan sistem pembelajaran tematik. "

\begin{tabular}{cc}
\multicolumn{2}{c}{ Pernyataan di atas dipertegas } \\
dengan $\quad$ hasil
\end{tabular}
penulisbersama Ustazah(U4) sebagai wali kelas III Al-Qardawi pada tanggal 30 Mei 2011 yang menyatakan bahwa:

"Menurut saya pembentukan karakter pada murid mengacu kepada pembentukan akhlak yang baik kepada 
anak sebagaimana yang diajarkan oleh Rasulullah SAW dan mengacu juga kepada 10 muwasafat. "

Dan diperkuat dengan hasil wawancara penulis dengan Ustazah(U5) sebagai wali kelas $\mathrm{V}$ Al-Dahlawi pada tanggal $30 \quad$ Mei 2011 yang mengemukakan bahwa:

"Menurut saya yang dimaksud dengan pembentukan karakter itu artinya pembentukan watak dasar dari anak. Adapun bentuk dari pembentukan karakter murid di sekolah ini seperti dengan menanamkan nilai-nilai islami dari adab-adab yang baik yang di ajarkan oleh guru kepada murid, dan hal ini tidak hanya sekedar teori tetapi harus diterapakan terutama oleh guru, karena guru merupakan teladan bagi murid."

Senada dengan pernyataan sebelumnyaUstazah(U6) sebagai guru kelas II Ibnu Taymiyah pada tanggal 30 Mei 2011 juga yang menyatakan bahwa:

"Pembentukan karakter murid mengarah kepada pembentukan akhlak yang masuk kedalam aspek psikomotor. Pembentukan karakter murid bisa dilihat dari adanya Buku Monitoring Adab yang isi setiap hari kemudian dikumpulkan kepada wali kelas. Adapun sistem pengajaran yang saya terapkan di sini adalah sistem pembelajaran tematik dengan konsep terpadu yaitu menggabungkan antara teori, dalil-dalil dan prakteknya."

Penulis juga melalukan wawancara dengan Ustazah (U7) sebagai guru kelas VI Al-Khawarizmi pada tanggal 1 Juni 2011 yang mengakatan bahwa:

"Pembentukan karaker murid mengandung makna bahwa kita mengajarkan karakter tambahan dengan karakter islami dan guru sebagai tauladannya. Pembentukan karakter ini terlihat dari buku monitoring adab dan mentoring yang merupakan pengembangan dari 10 prinsip muwasafat. Dalam pembentukan karakter guru berperan sebagai pendidik, orang tua dan pembimbing. Salah satu langkah dalam pembentukan karakter murid terlebih setelah libur itu dengan mengadakan MOS selama 1 mingggu yang bertujuan untuk mengulang dan mengingatkan kembali pada diri anak tentang adab-adab yang telah diajarkan. “

Ungkapan tersebut ditegaskan lagi dengan hasil wawancara penulis bersama Ustazah(U8) sebagai wali kelas VI Al-Khawarizmi pada tanggal 1 Juni 2011 yang mengemukakan bahwa:

"Pembentukan karakter yang di sekolah ini lebih dikenal dengan sekolah berkarakter (Character School) mengandung arti bahwa bagaimana menjadikan sekolah ini sebagai berkarakter yang baik atau karakter yang positif lagi memiliki nilai atau atitude yang baik atau dikenal dengan karakter yang islami. Adapun program atau kegiatan yang mengarahkan pada pembentukan karakter seperti mengajarkan adab-adab islami antara lain sholat dhuha, tilawah disamping pada permulaanya diadakan matrikulasi tentang adab-adab islami, mentoring, dan kelompok belajar. Guru disamping berperan sebagai pendidik juga sebagai orang tua dengan istilah lainnya rumah kedua bagi anak, dan juga sebagai teman curhat tempat berbagi cerita dan permasalahan. "

Pernyataan di atas didukung oleh hasil wawancara penulis bersama Ustazah(U9) sebagai wali kelas II Ibnu Hambal pada tanggal 1 Juni 2011 yang mengemukakan bahwa:

"Pembentukan karakter itu mengarah pembentukan kepribadian anak. Disini kami menganggap semua anak sebagai sang juara artinya tidak ada anak yang bodoh mereka punya kelebihan atau kecerdasan di bidang yang berbeda atau dikenal dengan istilah multiple intelegensi. 
Pembentukan karakter anak terlihat dari pada awal dilaksanakannya proses belajar mengajar dengan diadakannya aturan kelas danbagi anak yang melanggar aturan tersebut akan dikenakan iqab (hukuman) misalnya berdiri, berwudhu, istighfar. Terkadang saya menggunkan metode tandur (Tumbuhkan, Alami, Namai, Demonstrasikan, Ulangi, dan Rayakan) dan strateginya dengan menggunakan nasyid sehingga hal ini membuat anak senang dalam belajar dan mudah dalam memahami pelajaran."

Ungkapan sebelumnya juga didukung dengan hasil wawancara penulis dengan Ustaz (U10) sebagai guru kelas IV Ibnu Hawqal dan guru bidang studi bahasa Arab pada tanggal 1 Juni 2011 yang mengemukakan bahwa:

"Pembentukan karakter pada diri anak berawal dari kebiasaan-kebiasaan yang baik sehingga menjadi kepribadian yang dinamakan karakter. Pada dasarnya anak itu pintar artinya tidak ada yang bodoh semua anak di kelas ini adalah sang juara walaupun mereka cerdas dalam bidang yang berbeda atau dikenal dengan istilah multiple intelegensi. Di kelas ini sudah diadakan mentoring yang merupakan salah satu pembentukan karakter pada anak. Selain itu, ada beberapa program atau kegiatan yang menunjang pembentukan karakter anak misalnya pelaksanaan sholat dhuha dan tilawah alqur'an setiap hari. Guru disamping sebagi pendidik juga berperan sebagai orang tua dan teman bagi anak tempat berbagi cerita dan curhat sehingga tidak ada jarak antara guru dengan murid seperti yang terjadi di sekolah umum lainnya, dimana anak segan dengan guru."

\section{Temuan Khusus Penelitian Buku Monitoring Adab}

Buku Monitoring Adab (BMA) ini sengaja diadakan untuk membantu dalam penilaian aspek afektif dan psikomotor siswa secara mandiri disamping juga untuk memupuk self control pada diri masing-masing siswa. Agar implementasi BMA dapat berjalan secara efektif maka setiap komponen yang terlibat di dalamnya: siswa, orang tua dan wali kelas agar membaca secara seksama petunjuk teknis dan memahaminya dengan baik.

Bagi para siswa diharapkan BMA ini sebagai rambu-rambu dalam bersikap dan berprilaku sehari-hari baik terhadap orang tua, guru, teman atau siapun di mana dan kapan saja. Sebab yang terdapat dalam BMA ini semuanya adalah baik dan menguntungkan siswa tidak ada satu pun yang merugikan.

Bagi orang tua siswa, BMA ini bisa membantu dalam membimbing dan mengarahkan anak-anak dirumah. Sehingga perilaku dan sikap baik dan fositif yang menjadi harapan setiap orang tua dapat terwujud.

Bagi guru dan wali kelas, BMA ini merupakan dasar dalam memberikan nilai untuk ranah afektif dan psikomotor. BMA ini dapat membantu dalam memberikan data yang valid dan akurat. 
Buku Monitoring Adab (BMA) Kelas I

Monitoring Akhlak dan Perilaku Utama

Siswa Kelas I

SDIT AlFityah Tampan Pekanbaru Riau

Bulan : .................................... Pekan ke :.

\begin{tabular}{|l|l|l|l|l|l|l|l|l|l|}
\hline $\begin{array}{c}\text { Akhlah dan Perilaku } \\
\text { Penunjang (Kaffarat) }\end{array}$ & Bobot & Ahad & Senin & Selasa & Rabu & Kamis & Jum'at & Sabtu & Jumlah \\
\hline $\begin{array}{c}\text { 1. Melakukan Muraja'ah } \\
\text { Hapalan }\end{array}$ & S (1) & & & & & & & & \\
\hline $\begin{array}{l}\text { 2. Shalat lima waktu } \\
\text { 3. Beristinja' dan berwu- B }(1,5) \\
\text { dhu' dengan baik dan } \\
\text { benar }\end{array}$ & & & & & & & & \\
\hline 4. Berkata jujur & $\mathrm{B}(1,5)$ & & & & & & & & \\
\hline $\begin{array}{l}\text { 5. Membantu orang tua } \\
\text { R }(0,5)\end{array}$ & & & & & & & & \\
\hline $\begin{array}{c}\text { 6. Berbicara lemah lembut } \\
\text { (sopan) }\end{array}$ & $\mathrm{S}(1)$ & & & & & & & & \\
\hline $\begin{array}{c}\text { 7. Mengikuti proses belajar } \\
\text { dengan baik dan benar di } \\
\text { sekolah }\end{array}$ & $\mathrm{S}(1)$ & & & & & & & & \\
\hline Jumlah Poin Per Hari & 8 & & & & & & & & \\
\hline Jumlah Poin Per Pekan & 56 & & & & & & & & \\
\hline
\end{tabular}

Pekanbaru, ......................20....

Dilaporkan oleh,

\section{$(\cdot \ldots \ldots \ldots \ldots \ldots \ldots \ldots . . .$.}

Penulis melihat bahwa Buku Monitoring Adab (BMA) siswa pada Kelas I, dimana Monitoring Akhlak dan Perilaku Utama mencakup beberapa aspek diantaranya: Aspek Shahihul Ibadah (Ibadah yang benar), seperti shalat lima waktu dan beristinja' dan berwudhu' dengan baik dan benar, hal ini mengajarkan kepada anak didik agar terbiasa berwudhu dan melaksanakan sholat lima waktu sesuai dengan syari'at Islam yang merupakan kewajiban setiap muslim yang perlu dibiasakan pada diri anak sejak dini sehingga ketika mereka dewasa nanti akan terbiasa melaksanakan ibadah wajib tanpa harus di suruh tetapi ini menjadi kebutuhan dalam hidupnya.

Aspek Matinul Khuluq (Akhlak yang kokoh) seperti, berkata jujur dan membantu orang tua, serta berbicara lemah lembut atau sopan, hal ini
1. Bapak/Ibu
Diketahui oleh,
2. Teman Sejawat
3. Wali Kelas

mengajarkan kepada anak agar membiasakan prilaku yang baik sebagaimana yang diajarkan oleh Rasullah SAW sehingga diharapkan anak mejadi pribadi yang memiliki akhlak yang terpuji. Aspek Mutsaqqoful Fikri (Intelek dalam berpikir), seperti melakukan muraja'ah hapalan, hal ini dilakukan agar anak terbiasa berinteraksi dengan Al-Qur'an dan melatih daya ingatannya dalam berpikir. Aspek Munazhzhamun fi Syuunihi (teratur dalam urusan) seperti mengikuti proses belajar dengan baik dan benar di sekolah, hal ini diajarkan agar anak terbiasa bersungguh-sungguh dalam mencari ilmu dengan cara mengukiti proses belajar dikelas dengan baik sehingga mereka mudah dalam menerima ilmu yang diberikan oleh bapak/ibu guru di sekolah. 
Penulis sendiri juga melakukan observasi secara langsung sebelum para murid memasuki lapangan sekolah, para guru atau ustaz/ustazah berdiri dekat pintu pagar menyambut kedatangan para murid dengan ucapan salam dan senyuman, dimana para murid bergatian menyalami gurunya satu persatu. Untuk murid kelas I sampai III boleh menyalami semua gurunya baik ustaz maupun ustazah, tetapi untuk murid kelas IV sampai kelas VI hanya boleh menyalami ustaz atau ustazahnya. Dengan kata lain murid laki-laki hanya boleh menyalami ustaznya saja. Sedangkan murid perempuan hanya boleh menyalami ustazahnya saja. Penulis berpandangan bahwa ini adalah salah satu cara guru untuk mengajarkan akhlak yang baik kepada murid, sehingga diharapkan murid bisa membiasakannya dan menanamkan dalam dirinya kebiasaan yang baik yang pada akhirnya menjadi karakter pada diri anak itu sendiri.

Setelah bersalaman dengan para murid, penulis masuk ke salah satu kelas kemudian mengamati apa yang dilakukan oleh guru terhadap anak didiknya, penulis melihat bahwa sebelum aktivitas belajar mengajar di mulai, para murid diminta untuk melaksanakan shalat dhuha dan dilanjutkan dengan membaca ayat AlQur'an atau sering disebut dengan istilah tilawah Al-Qur'an. Kemudian sebelum belajar para murid membaca do'a secara bersama-sama setelah itu belajar sesuai jam pelajaran pada sa'at itu. Dalam pemberian materi pelajaran terkadang ustazahnya menyanyikan beberapa lagu agar anak didiknya bersemangat dan mudah dalam memahami pelajaran yang diberikan, dan bagi anak yang mendapatkan nilai bagus akan mendapatkan reward atau hadiah dari ustazahnya.

Selain itu penulis juga melihat bahwa ada beberapa program atau kegiatan yang menunjang pembentukan karakter anak misalnya pelaksanaan sholat dhuha, muraja'ah dan tilawah AlQur'an yang dilakukan setiap hari yang dibimbing oleh ustaz atau ustazahnya. Dalam pembentukan atau penanaman karakter yang baik di dalamnya harus ada kebersamaan antara siswa dengan guru.

\section{PEMBAHASAN}

\section{Pembentukan Karakter Murid di Sekolah Dasar Islam Terpadu Al- Fityah Pekanbaru}

Dari petikan semua wawancara di atas setelah penulis membandingkan hasil wawancara satu dengan yang lain serta wawancara dengan hasil observasi dan diperkuat dengan data dokumentasi, maka dapat diketahui bahwa pembentukan karakter yang di terapkan di sekolah ini lebih dikenal dengan sekolah berkarakter (Character School) mengandung arti bahwa bagaimana menjadikan sekolah ini sebagai sekolah berkarakter yang baik atau karakter yang positif lagi memiliki nilai atau atitude yang baik atau dikenal dengan karakter yang islami. Disamping itu, dikatakan juga bahwa Pembentukan karakter pada murid mengacu kepada pembentukan akhlak yang baik bagi anak, sebagaimana yang diajarkan oleh Rasulullah SAW dan mengacu juga kepada 10 muwasafat dengan menanamkan nilai-nilai islami dari adab-adab yang baik yang di ajarkan oleh guru kepada murid kemudian diamalkan.

Dalam proses pembelajaran di kelas I sampai Kelas III dalam sistem pembelajarannya menggunakan tematik yaitu dengan menentukan tema dikuatkan dengan dalail-dalil dari AlQur'an kemudian dihubungkan dengan keseharian siswa, dan pada kelas IV sampai kelas VI sistem pembelajarannya dengan menggunakan metode active 
learning yang menuntut siswa aktif dalam proses pembelajaran dengan kata lain tidak semata-mata doktrin dari guru tetapi anak punya persepsi tersendiri. Di sini juga guru memadukan nilai-nilai dengan pelajaran artinya tidak murni pelajaran saja tetapi perlu juga untuk dipraktekkan atau menghubungkan pelajaran dengan kehidupan sehari-hari anak.

Sedangkan sistem pengajaran yang diterapkan di Sekolah Dasar Islam Terpadu Al Fityah Pekanbaru adalah sistem pembelajaran tematik dengan konsep terpadu yaitu menggabungkan antara teori, dalil-dalil dan prakteknya.

Adapun program atau kegiatan yang mengarahkan pada pembentukan karakter murid sepertipada permulaan tahun ajaran baru diadakan matrikulasi tentang adab-adab islami. Kemudian mengajarkan adab-adab islami, ada mentoring yang merupakan salah satu pembentukan karakter pada anak. Selain itu ada beberapa program atau kegiatan yang menunjang pembentukan karakter anak misalnya pelaksanaan sholat dhuha, muraja'ah dan tilawah AlQur'an setiap hari. Dalam pembentukan atau penanaman karakter yang baik di dalamnya ada kebersamaan antara siswa dengan guru.

Ada beberapa langkah yang dilakukan dalam proses pembentukan karakter murid di Sekolah Dasar Islam Terpadu Al-Fityah Pekanbaru, seperti mengulang adab-adab islami yang sudah diajarkan, monitoring siswa di lingkungan sekolah. Kemudian setelah libur itu diadakan MOS selama 1 mingggu yang bertujuan untuk mengulang dan mengingatkan kembali pada diri anak tentang adab-adab yang telah diajarkan.Adapun langkah yang diambil ketika menghadapi anak yang bermasalah dalam karakternya seperti, mengingatkannnya dengan teguran dan nasehat kemudian memberikan iqab jika diperlukan.
Dan prinsip yang dikembangkan dalam pembentukan karakter ini berpijak pada 10 muwasafat yang kemudian diterjemahkan kedalam nilai atau atitude diantaranya yang terdapat pada point di buku monitoring adab yang sangat berpengaruh terhadap hasil ujian akhir semester murid sebanyak $20 \%$. Hal ini terlihat dari hasil lapor akhir semester anak yang diperoleh dengan cara mengevaluasi hasil dari Buku monitoring adab kemudian diambil $20 \%$ lalu ditambahkan dengan hasil ujian semester dan dijumlahkan sehingga akan terlihat berapa hasil keseluruhan aspek penilaian dari guru yang meliputi aspek kognitif, afektif dan psikomotor.

Untuk mengetahui pembentukan karakter anak, disini penulis berpedoman kepada pendapat dari beberapa orang tokoh diantaranya, Imam Al-Ghazali mengatakan bahwa sumber pembentukan karakter yang baik itu dapat dibangun melalui internalisasi nama-nama Allah (asma' alHusna) dalam perilaku seseorang. Dengan kata lain untuk membangun karakter yang baik, sejauh kesanggupannya, hendaknya seorang anakmelaui bimbingan dari gurunya untuk membiasakan sifat-sifat ketuhanan, seperti pengasih, penyayang, pengampun (pemaaf), dan sifat-sifat yang disukai Tuhan, sabar, jujur, takwa, zuhud, ikhlas beragama, dan sebagainya. Kemudian Imam Hasan al-Banna juga mengatakan bahwa pembentukan karakter seorang muslim juga dapat terbentuk dari adanya 10 sifat atau muwasafat yang harus dimilikioleh seseorang, yaitu Salimul Aqidah (Aqidah yang bersih), Shahihul Ibadah (Ibadah yang benar), Matinul Khuluq (Akhlak yang kokoh), Qowiyyul Jismi (kuat jasmani), Mutsaqqoful Fikri (Intelek dalam berpikir), Mujahadatul Linafsihi (Berjuang Melawan hawa nafsu), Harishun Ala Waqtihi (Pandai menjaga 
waktu), Munazhzhamun fi Syuunihi (teratur dalam urusan), Qodirun Alal Kasbi (mampu berusaha sendiri atau mandiri), Nafi'un Lighoirihi (bermanfa'at bagi orang lain).

Guru disamping berperan sebagai pendidik juga sebagai orang tua dengan istilah lainnya rumah kedua bagi anak, dan juga sebagai teman curhat tempat berbagi cerita dan permasalahan.

Peran guru dalam tahapan proses pembentukan karakter sangat penting. Guru membantu membentuk karakter peserta didik. Hal ini mencakup keteladanan bagaimana perilaku guru, cara guru berbicara atau menyampaikan materi, bagaimana guru bertoleransi, dan berbagai hal terkait lainnya. pembentukan karakter anak atau akhlak pada prinsipnya dapat terwujudkan jika ada figur yang pantas dijadikan teladan yang baik (uswatun hasanah), kalau di sekolah berarti gurulah yang menjadi teladan bagi anak didiknya begitu juga dirumah orang tualah yang menjadi teladan yang baik bagi anaknya.

Selain itu, waktu belajar peserta didik di sekolah perlu dioptimalkan agar peningkatan mutu hasil belajar dapat dicapai, terutama dalam pembentukan karakter peserta didik. Di Sekolah Dasar Islam Terpadu ini telah menerapkan waktu belajar fullday, dimana waktu belajar murid di sekolah ini lebih lama dibandingkan dengan sekolah lainnya dimulai pukul 7.30 -16.00 WIB. Para murid di sekolah ini setiap hari belajar yaitu senin sampai jum'at kecuali hari sabtu untuk kegiatan ekstrakurikuler.

Kegiatan ekstra kurikuler yang selama ini diselenggarakan sekolah merupakan salah satu media yang potensial untuk pembinaan karakter dan peningkatan mutu akademik peserta didik. Kegiatan Ekstra Kurikuler merupakan kegiatan pendidikan di luar mata pelajaran untuk membantu pengembangan peserta didik sesuai dengan kebutuhan, potensi, bakat, dan minat mereka melalui kegiatan yang secara khusus diselenggarakan oleh pendidik dan atau tenaga kependidikan yang berkemampuan dan berkewenangan di sekolah. Melalui kegiatan ekstra kurikuler diharapkan dapat mengembangkan kemampuan dan rasa tanggung jawab sosial, serta potensi dan prestasi peserta didik.

Berdasarkan hal ini diketahui bahwa tahapan pembentukan karakter murid di Sekolah Dasar Islam Terpadu Al Fityah Pekanbaru terlihat dari diantaranya Kurikulum yang merupakan inti dari sebuah lembaga pendidikan, pengelola sekolah ini sangat cocern terhadap perkembangan terkini dari sebuah kurikulum, ada tiga kurikulum pokok yang digunakan: (1)Kurikulum Depdiknas, dimana Kurikulum ini dimodifikasi sedemikian rupa dan diperkaya dengan nilai-nilai keislaman dan kemelayuan sehingga dapat memenuhi target-target out put siswa yaitu melahirkan siswa yang berprestasi, berakhlaq islami, dekat dengan Al-Qur'an serta mampu mengenal dan berinteraksi dengan lingkungannya; (2)Kurikulum Matrikulasi, Kurikulum ini diadakan dalam rangka menunjang kelancaran efektifitas segala kegiatan secara integral, materi yang diberikan antara lain:Budaya dan motto SDIT Al Fityah, Adab-adab sehari-hari,12 Karakter siswa SDIT Al-Fityah. Matrikulasi ini diberikan pada awal tahun pelajaran untuk seluruh siswa baik yang baru maupun yang lama, lama program lebih kurang 2 bulan; dan (3) Kurikulum Khas SDIT Al FityahKurikulum khas ini mencakup:Tahsin dan Tahfiz, Bahasa Arab,Pramuka SIT, Pembinaan keislaman (mentoring Islam) khusus pada kelas IV sampai kelas VI.

Ketiga bentuk kurikulum di atas diterapkan secara terpadu untuk mencapai out put siswa yang berakidah 
bersih, ibadah shahih, pola pikir beradab, akhlak kuat, fisik sehat, pribadi militan, disiplin, efesien, bermanfaat dan mandiri. Dengan kata lain bisa mencapai 10 muwasafat.

Disamping itu tahapan pembentukan karakter murid juga terlihat dari Program pembelajaran dan pendidikan di SDIT Al Fityah secara garis besar meliputi: (1) Matrikulasi. Program ini dilaksanakan pada awal tahun pelajaran berlansung selama 2 bulan terutama untuk murid baru yang berada di kelas I, (2) Kurikuler. Program ini diimplementasikan melalui pendekatan mastery learning, field trip, assembly, eksplorasi (3).Ekstra Kurikuler. Program ini diadakan untuk mengembangkan minat dan bakat siswa, mencakup:Renang (wajib), Taekwondo, Teater, Nasyid, Sepak bola, Dokter kecil, Sempoa, Olympiade Sains, Olympiade dan matematika, Kaligrafi dan Karikatur, Library Service, Jarimatika, Rebana, dan Manggambar/melukis.

Pembentukan karakter yang baik di lingkungan sekolah lansung dibimbing dan diperhatikan oleh guru atau dikenal dengan sebutan ustaz/ustazah, sedangkan di rumah pembentukan karakter pada diri anak dibimbing oleh kedua orang tuanya melalui Buku Monitoring Adab (BMA) yang mesti diisi setiap hari sesuai dengan kegiatan yang dilakukan oleh anak kemudin dievaluasi oleh guru di sekolah.

Faktor-faktor yang mempengaruhi pembentukan Karakter Murid di Sekolah Dasar Islam Terpadu AlFityah Pekanbaru

Berdasarkan hasil wawancara sebelumnya dari beberapa orang guru yang penulis wawancarai serta didukung oleh hasil observasi dan diperkuat dengan data dokumentasi, maka dapatlah diketahui bahwa ada beberapa faktor yang mempengaruhi pembentukan karakter murid di Sekolah Dasar Islam Terpadu Al Fityah Pekanbaru, yaitu: faktor keluarga atau orang tua, teman, lingkungan, dan pengaruh televisi serta media elektronik lainnya termasuk internet.

Adapun bentuk-bentuk pengaruh tersebut diantaranya: kebiasaan di rumah yang kurang baik, orang tua yang kurang perhatian pada pembentukan karakter anaknya, pola asuh orang tua di rumah, perbedaan cara pandang antara orang tua dan guru, orang tua dan guru tidak bisa memenuhi kebutuhan anak seutuhnya, nilai-nilai yang diterapkan di rumah berbeda dengan apa yang diajarkan di sekolah, pengaruh lingkungan termasuk teman yang memilki kebiasaan yang kurang baik, anak tidak jujur dalam pengisian buku Monitoring Adab, berkata kotor, berkelahi dengan teman, terkadang tidak ucapkan salam sebelum masuk kelas.

Dari beberapa faktor yang dikemukakan diatas berdasarkan hasil wawancara penulis dengan beberapa ustaz/ah diketahui bahwa keluarga berperan sebagai faktor yang sangat besar pengaruhnya dalam pembentukan karakter pada diri anaknya.Orang tua adalah teladan pertama bagi pembentukan pribadi anak. Perilaku kedua orang tua dengan sendirinya memiliki pengaruh yang sangat dalam terhadap pemikiran dan perilaku anaknya.Dan yang paling penting adalah bahwa orang tua adalah satu-satunya teladan yang pertama bagi anakanaknya dalam pembentukan kepribadian, begitu juga anak secara tidak sadar mereka akan terpengaruh, maka kedua orang tua di sini berperan sebagai teladan bagi mereka baik teladan pada tataran teoritis maupun praktis. Maka kedua orang tua sebelum mereka mengajarkan nilai-nilai agama dan akhlak kepada anak-anaknya, 
pertama mereka sendiri harus mengamalkannya terlebih dahulu.

Disamping itu, Lingkungan juga berpengaruh dan memiliki peran yang penting dalam mewujudkan karakter anak.Lingkungan adalah sesuatu yang berada di luar batasan-batasan kemampuan dan potensi genetik seorang anak. Lingkungan adalah faktor luar yang berpengaruh dalam pembentukan dan perubahan kepribadian anak. baik itu lingkungan alam, lingkungan ekonomi dan lingkungan sosial. Lingkungan sosial juga mencakup lingkungan keluarga, sekolah dan sebaginya.

Faktor lain yang juga mempengaruhi karakter anak, yaitu teman. jika seorang anak berteman dengan anak yang memiliki kepribadian yang baik maka anak tersebut akan menjadi anak yang memiliki karakter yang baik, sebaliknya jika seorang anak berteman dengan anak yang memiliki kepribadian yang buruk maka anak tersebut akan menjadi anak yang memiliki karakter yang buruk.

Media elektronik juga ikut andil dalam mempengaruhi karakter anak, diantaranya dengan beragamnya tayangan televisi yang terkadang tidak semestinya ditonton oleh anak akan mempengaruhi karakter anak karena biasanya anak akan mencoba untuk meniru apa yang mereka lihat di televisi. Di samping itu juga, pengaruh dari media internet jika disalahgunakan akan memberikan dampak negatif kepada pembentukan karakter anak.

Dari keterangan di atas dapat disimpulkan bahwa ada beberapa faktor yang mempengaruhi pembentukan karakter murid di Sekolah Dasar Islam Terpadu Al Fityah Pekanbaru, yaitu: faktor keluarga atau orang tua, teman, lingkungan, dan ditambah dengan pengaruh televisi serta media elektronik lainnya termasuk internet.

\section{SIMPULAN}

Berdasarkan temuan-temuan penelitian yang telah dikemukakan di atas, penulis dapat menyimpulkan bahwa: Pertama, Pembentukan Karakter murid di Sekolah Dasar Islam Terpadu Al-Fityah Pekanbaru pada hakikatnya bagaimana pendidik mengajarkan dan menanamkan adab-adab yang islami kepada peserta didik kemudian membiasakannya dalam kehidupan sehari-hari baik di lingkungan sekolah maupun di lingkungan rumah dengan mengacu kepada 10 muwasafat, yaitu: Salimul Aqidah (Aqidah yang bersih), Shahihul Ibadah (Ibadah yang benar), Matinul Khuluq (Akhlak yang kokoh), Qowiyyul Jismi (kuat jasmani), Mutsaqqoful Fikri (Intelek dalam berpikir), Mujahadatul Linafsihi (Berjuang Melawan hawa nafsu), Harishun Ala Waqtihi (Pandai menjaga waktu), Munazhzhamun fi Syuunihi (teratur dalam urusan), Qodirun Alal Kasbi (mampu berusaha sendiri atau mandiri), Nafi'un Lighoirihi (bermanfa'at bagi orang lain).Pembentukan karakter yang baik di lingkungan sekolah langsung dibimbing dan diperhatikan oleh guru, sedangkan di rumah pembentukan karakter pada diri anak di bimbing oleh kedua orang tuanya melalui Buku Monitoring Adab (BMA) kemudian dievaluasi oleh guru di sekolah.

Adapun Tahapan proses pembentukan karakter ini terlihat dari Program atau kegiatan yang mengarahkan pada pembentukan karakter di mana pada permulaanya diadakan matrikulasi tentang adab-adab islami, mengajarkan adab-adab islami, diadakannya mentoring, program atau kegiatan yang lainnya seperti pelaksanaan sholat dhuha, muraja'ah dan tilawah alqur'an setiap hari.

Kedua, Ada beberapa faktor yang mempengaruhi pembentukan Karakter 
Murid di Sekolah Dasar Islam Terpadu Al-Fityah Pekanbaru yaitu: faktor keluarga atau orang tua, teman, lingkungan, dan pengaruh televisi serta media elektronik lainnya termasuk internet.Adapun bentuk-bentuk pengaruh tersebut diantaranya: kebiasaan di rumah yang kurang baik, orang tua yang kurang perhatian pada pembentukan karakter anaknya, pola asuh orang tua di rumah, perbedaan cara pandang antara orang tua dan guru, orang tua dan guru tidak bisa memenuhi kebutuhan anak seutuhnya, nilai-nilai yang diterapkan di rumah berbeda dengan apa yang diajarkan di sekolah, pengaruh lingkungan termasuk teman yang memilki kebiasaan yang kurang baik, anak tidak jujur dalam pengisian buku Monitoring Adab, berkata kotor, berkelahi dengan teman, terkadang tidak ucapkan salam sebelum masuk kelas.

\section{DAFTAR PUSTAKA}

Abdullah, Abdurrahman Saleh. 2007. Teori-Teori Pendidikan Berdasarkan Al-Qur'an. Jakarta: PT. Rineka Cipta.

Agustian, Ary Ginanjar. 2001. Rahasia Sukses Membangun Kecerdasan Emosi dan Spritual ESQ, Emotional Spritual Quotient berdasarkan 6 Rukun Iman dan 5 Rukun Islam. Jakarta: Arga Wijaya Persada.

Al-Banna, Hasan. Majmu'atur Rasail Hasan Al-Banna (Kumpulan Risalah Dakwah Hasan Al-Banna). Penerjemah, Khozin Abu Faqih.Jakarta: Al-I'tishom Cahaya Umat, 2006.

Al-Ghazali, Muhammad. 2002. Memahami Islam Cara Terbaik menanamkan Nilai-Nilai Agama. Jakarta: PT.Raja Grafindo Persada.

Beck, Joan. Meningkatkan Kecerdasan Anak. Delapratasa Publishing, 2003.
Booby Deporter, Mike Hernacki. Quantum learning: Unleashing The Genius In You (Quantum Learning: Membiasakan Belajar Nyaman dan Menyenangkan), Dell Publishing, New York, 1992. Penerjemah, Alawiyah Abdurrahman, Bandung: Kaifa, 2000.

Connell, Helen. 2003. Reformasi Pendidikan. Jakarta: PT Logos Wacana Ilmu.

Emzir. 2010. Metodologi Penelitian Pendidikan: Kuantitatif dan Kualitatif, Jakarta: Rajawali Press.

Ghony, Djunaidi. 1982. Hakekat Ilmu Pengetahuan dalam Pendidikan. Surabaya:PT Usaha Nasional.

Jasmine, Julia. 2007. Profesional's Giude: Teaching with Multiple Intellegences (Panduan Praktis Mengajar Berbasis Multiple Intelligences). Penerjemah Purwanto.Bandung: PT. Nuansa.

Jauhari, Muchtar Heri. 2005. Fikih Pendidikan, Bandung: PT.Remaja Rosdakarya.

Karim, Nazir. 2004. Membangun Ilmu dengan Paradigma Islam. Pekanbaru: PT Suska Press.

Kesuma, Dharma, et,al., 2011. Pendidikan Karakter Kajian Teori dan Praktik di Sekolah, Bandung: PT. Remaja Rosdakarya.

Koesoema, Doni. Pendidikan Karakter Strategi Mendidik di Zaman Global, Jakarta: PT.Grasindo, 2010

Madjidi, Busyairi. 1997. Konsep Kependidikan Para Filosof Muslim, Yogyakarta: Al-Amin Press.

Mahmud, Ali Abdul Halim. 1997. Mahaj at-Tarbiyah inda al-Ikhwanul Muslimin (Metode Pendidikan Ikhwanul Muslimin). Penerjemah, Masykur Hakim, Ubaidillah, Jakarta: Gema Insani Press.

Megawangi, Ratna. 2004. Pendidikan Karakter Solusi yang Tepat untuk Membangun Bangsa. Jakarta. 
Muhaimin, et,al., 2004. Paradigma Pendidikan Islam upaya mengefektifkan Pendidikan Agama Islam di sekolah. Bandung: PT. Remaja Rosdakarya.

Muhmidayeli. 2007. Teori-Teori Pengembangan Sumber Daya Manusia, Pekanbaru: LSFK2P.

Muhmidayeli. 2005. Filsafat Pendidikan Islam. Pekanbaru: LSFK2P.

Mujib, Abdul, et,al., 2008. Ilmu Pendidikan Islam. Jakarta: PT Prenada Media Group.

Muslich, Mansur. 2011. Pendidikan Karakter Menjawab Tantangan Krisis Multidimensional. Jakarta: PT. Bumi Aksara.

Moleong,Lexy. J., 2004. Metode Penulisan Kualitatif, Bandung: PT. Remaja Rosdakarya.

Nata, Abuddin. 2009. Tafsir Ayat-Ayat Pendidikan (Tafsir Al-Ayat AlTarbawiy), Jakarta: Rajawali Press.

Nasution, Thomas. 2010. Buku Penuntun membuat Tesis, Skripsi, Disertasi, Makalah, Jakarta: PT. Bumi Aksara.

Nizar,Samsul. 2009. Hakekat Manusia dalam Perspektif Pendidikan Islam; Membangun Pola Pendidikan yang Humanistik. Pekanbaru: Suska Press.

Prayitno. 2009. Dasar Teori dan Praktis Pendidikan. Jakarta: PT. Grasindo.
Purwanto, Ngalim. 2000. Ilmu Pendidikan Teoretis dan Praktis. Bandung : PT Remaja Rosdakarya. Ramayulis. 2002. Ilmu Pendidikan Islam. Jakarta : PT Kalam Mulia.

Shaleh Abdul, Rachman. 2006. Pendidikan Agama \& Pembangunan Watak Bangsa. Jakarta: PT Raja Grafindo Persada.

Silbermen, Melvin. L. Allyn and Bacon. 1996. Active Learning: 101 Strategies to Teach Any Subject (Active Learning: 101 Cara Belajar Siswa Aktif) Penerjemah. Raisul Muttaqien, Bandung: Nusamedia, 2006.

Sudirman,N. Dkk., 1987. Ilmu Pendidikan. Bandung: CV.Remaja Karya.

Sukardi. 2005. Metodologi Penelitian Pendidikan Kompetensi dan Praktiknya, Jakarta: PT. Bumi Aksara.

Suryadi Ace, Tilaar. 1994. Analisis Kebijakan Pendidikan. Bandung: PT Remaja Rosdakarya.

Suwendi. Sejarah dan Pemikiran Pendidikan Islam. Jakarta: PT Raja GrafidoPersadano.

Tafsir, Ahmad. 2008. Ilmu Pendidikan dalam Perspektif Islam. Bandung: PT.Remaja Rosdakarya.

Wijaya Cece.dkk., 1992. Upaya Pembaharuan Dalam Pendidikan dan Pengajaran. Bandung : PT. Remaja Rosdakarya. 